\title{
Svensk barn- och ungdomslitteratur $i$ Frankrike - från Nils till Semlan: Ställning, urval och anpassning
}

Annelie Jarl Ireman

Université de Caen Normandie

I Frankrike blev barnlitteraturen betydelsefull på I920-talet då Hachette startade serien Bibliothèque verte och Bibliothèque rose bytte namn till Bibliothèque rose illustrée och utvecklades. Efter I945 bestod genren till stor del av utgivningen av klassiker (som Dumas och Verne) som ansågs vara god litteratur för unga, ofta i versioner som låg långt från originalet då de anpassades till barn, varvid den litterära kvaliteten blev lidande (Delbrassine, 2006: 20). Pedagogiska, moraliska och editoriella faktorer definierar nämligen denna genre. På 70-talet sker en viktig utveckling då läsnöjet börjar betonas mer än den pedagogiska aspekten vilket medför att de narrativa möjligheterna blir fler då de moraliska kraven delvis släpps och böckerna blir mer realistiska. Idag finns det böcker som behandlar även svåra ämnen som mobbning, incest och död och några böcker innehåller dessutom grammatiskt inkorrekt språk ${ }^{\mathrm{I}}$. Det är en dynamisk genre och trots stor konkurens har en hel del svenska böcker funnit sin väg till Frankrike. Efter att ha visat att den franska barn- och ungdomslitteraturen ${ }^{2}$ fortfarande är underställd vissa villkor, presenterar artikeln den svenska BU-litteraturens ställning i Frankrike. Vidare studeras tre klassiker som kommit ut i olika versioner och avslutningsvis diskuteras varför översättningen av den nutida realistiska ungdomsromanen kan vara problematisk.

\section{BU-genren i Frankrike}

Många av dagens franska författare förklarar att de skriver för att ge unga läsare böcker som handlar om deras egna liv. Författaren har en

How to cite this book chapter:

Jarl Ireman, A. 20I5. Svensk barn- och ungdomslitteratur i Frankrike - från Nils till Semlan: Ställning, urval och anpassning. In: Cedergren, M. et Briens, S. (eds.) Médiations interculturelles entre la France et la Suède. Trajectoires et circulations de I945 à nos jours. Pp. 2I7-233. Stockholm: Stockholm University Press. DOI: http:// dx.doi.org/ıo.I6993/bad.q. License: CC-BY 
viss ålder i åtanke under skrivandet och försöker sätta sig in i läsarens känslomässiga liv, vilket inte hindrar att den pedagogiska intentionen finns kvar. Målet är att öka läskompetensen hos läsaren, samtidigt som hen får lära sig om livet och samhället via ämnen som vänskap och sorg (Routisseau, 2008: 75-76). Dessutom bestäms ofta åldersgruppen på de tänkta läsarna i förlagens serier. Man tänker i termer av ålder och kön. Författaren bör alltså anpassa sig till läsarens förutsatta kognitiva kompetens, genom att begränsa informationen och berättarstrukturen (Routisseau, 2008: 2I-22). Termen adaptation används främst för att tala om vuxenromaner som skrivs om för att passa barn (Nikolajeva, I996: 48; Delbrassine, 2006: I 8733). Många BU-författare följer dock dessa implicita regler. Det handlar i stort om att ha många dialoger med tydlig typografisk form, enkla ord, narration i jag-form, presens, enkel intrig, korta kapitel och stycken (vilket hjälper den oerfarna läsaren att ta sig igenom boken). Behovet av en sådan adaptation diskuteras mycket, även i Frankrike, där det samtidigt anses viktigt att inte sänka stilnivån när man anpassar berättelser till en ung publik. Meningarna får vara krångliga och strukturen kan även den vara avancerad. Men tydligt är att de tematiska och narrativa valen styrs av den tänkta läsargruppen (Delbrassine, 2006: I93). Det handlar för det mesta också om att att undvika våldsamma och sexuella scener och att ha lyckliga slut. Man kan konstatera att det inom BU-genren i Frankrike sker en sorts självcensur av både författare och förlag.

Den franska BU-boksproduktionen är reglerad av en lag från I949 som skapades i syfte att kontrollera framför allt amerikanska tecknade serier men också annan litteratur för barn. På alla böcker inom denna kategori står det således: "Loi No ${ }^{\circ} 9-956$ du I 6 juillet I949 sur les publications destinées à la jeunesse". Andra paragrafen i lagen förbjuder publikation av böcker som på ett positivt sätt framställer lögn, stöld, lättja, sexuella utsvävningar och allt annat som kan förstöra barns moral. Etniska och sexistiska fördomar tillfördes I954 respektive 20 IO och 20I I ändrades till följande formulering:

[...] présentant un danger pour la jeunesse en raison de son caractère pornographique ou lorsqu'il est susceptible d'inciter à la discrimination ou à la haine contre une personne déterminée ou un groupe de personnes, aux atteintes à la dignité humaine, à l'usage, à la détention ou au trafic de stupéfiants ou de substances psychotropes, à la violence ou à tous actes qualifiés de crimes ou de délits ou de nature à nuire à l'épanouissement physique, mental ou moral de l'enfance ou la jeunesse4 ${ }^{4}$. 
Ordet "épanouissement" kan förstås i betydelsen att de unga läsarna inte ska hindras i sin positiva utveckling, vilket allmänt tolkas som att boken ska vara moraliskt korrekt och sluta lyckligt. Tydligt är att franska barn ska skyddas från hemskheter, åtminstone när de läser böcker. Lagen har ofta kritiserats eftersom den hindrar yttrandefriheten, men många försvarar den också. Ett av de mest kända inläggen i debatten är Marie-Claude Monchaux’ pamflett från I985, i vilken hon säger att våra barns mentala och moraliska hälsa inte får skadas genom att familjen bryts ner, lärarkåren föraktas, droger och sexuella avvikelser försvaras (Monchaux, I988: baksidetext). Pamfletten följdes av en motreaktion och problemromanen fick med hjälp av det utländska inflytandet franska efterföljare på 90-talet (Delbrassine, 2006: 77). Debatten blossade upp igen i slutet av 90-talet då en kampanj hade som syfte att visa behovet av censur för att skydda barnen (Soulé, I999). Även senare böcker har skapat polemik. T. Lenain kritiseras till exempel för att han skriver om alltför svåra ämnen (som pedofili) men också för att han är för pessimistisk. En utvecklingen kan dock konstateras då hans böcker trots kritik publiceras. Dessutom har scener som tidigare tagits bort kunnats återinföras i senare upplagor. ${ }^{5}$ Under det senaste decenniet har det kommit många böcker som handlar om död och sexualitet, men oftast på ett försiktigt, abstrakt och optimistiskt sätt.

Termen adaptation behövs också för att beskriva hur utländsk ungdomslitteratur ibland skrivs om under översättningsarbetet för att motsvara vad man i Frankrike anser passa målgruppen. Detta har kritiserats mycket på senare tid. Den spanska forskaren I. Pascua-Febles konstaterar till exempel: "We cannot deny the didactic role of children's literature but the forced manipulation, the purification is something completely different and inadmissible" (Pascua-Febles, 20I0: I63). Men som C. Térouanne, förlagsredaktör på Hachette Jeunesse Roman, förklarar hör adaptationen inte till en svunnen tid utan kan i vissa fall fortfarande vara nödvändig " pour mettre à la portée du jeune lecteur des œuvres qui autrement basculeraient irrémédiablement dans l'oubli" (Térouanne, 2008: 80). I Frankrike undersöker la "Commission de surveillance et de contrôle des publications destinées à l'enfance et à l'adolescence" alla nyutkomna böcker och tecknade serier fyra gånger om året. Ingen bok har hittills förbjudits men att lagen finns tvingar förlagen att vara försiktiga. Kommissionen har ibland krävt en åldersgräns för en bok, vilket skedde 2007 med Malin Lindroths bok Quand les trains passent som förbjöds för barn under $\mathrm{I} 5$ år. Förläggaren Thierry Magnier förklarar i en intervju att en anledning till censuren var att det 
kunde uppfattas som att våldtäkt försvarades i boken (Ramdani, 2004). Förlagens försiktighet visar sig i urvalet av böcker men också t.ex. i efterord och varningstexter på omslag. När G. Beckmans Déchirer le silence kom ut I976 tillfogades en I 6 sidor lång text om abort. I M. Nilssons Après le voyage scolaire (2007) finns en text på I,5 sida om droger med telefonnummer och mailadress till "Fil Santé Jeunes" och omslaget uppvisar följande varning: "Certaines scènes peuvent heurter la sensibilité des jeunes lecteurs."

Om boken trots allt kommer ut utan ändringar och går igenom övervakningskommissionens kontroll återstår ännu en institution att passera. Bibliotekarierna har makten att inte köpa in böcker med rykte om sig att inte vara korrekta eller att stoppa undan dem så att läsaren inte kommer åt dem (Delbrassine, 2006: 278). Detta gäller också bokhandlarna. Även utbildningsdepartementet spelar en stor roll då de publicerar listor över rekommenderad litteratur för skolelever. En bok har alltså en lång väg att gå innan den når sina unga läsare. Idag betonas emellertid vikten av att minska de vuxnas roll till förmån för barnet. ${ }^{6}$

\section{Den svenska BU-litteraturens översättare och ställning}

Översättningen av skandinaviska böcker till franska i allmänhet tog fart på I980-talet, då flera forskare inom nordistiken tog sig an både klassiker och samtida verk. De fick en viktig roll som kulturförmedlare, särskilt tack vare gedigna förord. Eftersom de flesta svenska författare tidigare inte översatts var det logiskt att börja med de som fått utmärkelser i Sverige. BU-böckerna förblev dock för det mesta oöversatta vilket kan bero på att genren fortfarande var föga värdesatt i Frankrike. Det måttliga intresset kanske även kan förklaras av att denna generation översättare var mansdominerad. En del BUböcker kom ut på 60-70- och 80-talen men genren har ökat i betydele från 90-talet. Kersti och Pierre Chapelet, Alain Gnaedig och Agneta Ségol har till exempel varit produktiva. Sedan några år tillbaka har en ny generation översättare etablerats, bland annat tack vare Svenska Institutets översättarseminarier. Tidigare publicerades ofta en författare hos olika förlag, medan tendensen idag är att ett förlag har "sina” författare och "sina” översättare. Det gör att översättarna kan ha mer arbete än de hinner med och att en bok kan ligga och vänta på att översättaren ska bli ledig. Visserligen råder det brist på översättare idag, men samtidigt är det svårt för nya översättare att komma in på förlagen. De franska översättarna har till stor del varit introduktörer. 
De har föreslagit böcker till förlagen eller insisterat på att få dem publicerade. Detta håller dock på att ändras i och med att den unga generationen arbetar mer på beställning, då förlagen väljer böckerna. De svenska litterära agenterna har också fått en större roll. Men om översättaren har en speciell relation till sin förläggare (vilket t. ex. är fallet med A. Ségol hos Thierry Magnier ${ }^{7}$ ) finns ett ömsesidigt förtroende och förläggaren ser översättaren som sakkunnig. Många översättare skriver recensioner för förlagen och får därmed en aktiv roll i urvalet.

Den svenska BU-litteraturens ställning i Frankrike är emellertid fortfarande svag. Få böcker får seriösa recensioner i tidningar. Ett undantag är A. Thor som fick Tam-tampriset för Une île trop loin 2003. Hon finns också med på listan över rekommenderade böcker från utbildningsdepartementet. Att hamna på den betyder att boken är erkänd och "passande" (vilket självklart ökar försäljningssiffrorna). Den senaste listan kom ut 20I3 och böckerna grupperas efter skolans stadier. ${ }^{8}$ Une ile trop loin finns som enda representant för svensk prosa på listan för högstadiet. Det finns ingen svensk bok för de första två stadierna (upp till 8 år). I tredje (9-I I år) finns Tu sais siffler, Johanna? (I997), Fifi Brindacier (1995) och Robert (1996). Le merveilleux voyage de Nils Holgersson à travers la Suède finns också med och den är klassad som “œuvre patrimoniale” (vid sidan av t.ex. Pinocchio).

Kunskapen om svensk BU-litteratur ökar dock tack vare forskning och olika forum som ägnar sig åt denna genre. Centre National de la littérature pour la jeunesse har en komplett samling av franska BUböcker men också en samling med utländsk litteratur. Deras tidskrift La Joie par les livres med stor spridning har vid ett flertal tillfällen ägnats åt skandinavisk litteratur. En annan instans som gör mycket för den svenska BU-litteraturens erkännande är Svenska institutet i Paris som ordnar författarbesök, konferenser, m.m. Festivalen Les Boréales i Caen, som är pluridisciplinär med betoning på litteratur, har satsat mycket på BU-genren, i samarbete med skolor och bibliotek. Redan I999 var temat "Paroles d'enfance" med inbjudna svenska författare som A. Höglund och P. Lindenbaum samt tre av de viktigaste ungdomsromanförfattarna i Sverige: P. Pohl, U. Stark och A. Thor. Under det senaste decenniet har BU-litteraturen haft en given plats under festivalen med författarmöten, konferenser, utställningar, filmer... Andra svenska ungdomsförfattare som deltagit är M. Nilsson, S. Casta, K. Mazetti och P. Nilsson. 20I I var ett exceptionellt år för nordisk litteratur i Frankrike, tack vare le Salon du livre i Paris. ${ }^{9}$ Av de 40 inbjudna nordiska författarna representerade A. Thor och J. Thydell svensk 
ungdomslitteratur. Tidskrifter ägnade temanummer åt Norden. Le Magazine Littéraire publicerade t.ex. en omfattande studie varav en artikel behandlade BU-litteratur (Jarl Ireman, 20II), vilket visar på ett större erkännande av denna genre i Frankrike.

Forskningen om BU-litteratur är generellt sett relativt ny i Frankrike, men är idag intensiv trots att den länge haft svårt att nå ett erkännande, på samma sätt som barnboksförfattare och deras översättare inte gärna setts som "riktiga" författare och översättare. Om svenska författare nämns av specialisterna så är det i allmänhet Astrid Lindgren, särskilt i genushänseende. (I La littérature de jeunesse av C. Chelebourg och F. Marcoin (2007) heter hon dock Lindberg!) Det ökade antalet konferenser vittnar emellertid om ökad kunskap om svensk ungdomslitteratur och en tendens till fördjupning. I Delbrassines avhandling Le roman pour adolescents aujourd'hui finns ett kapitel om utländska influenser där Sverige ägnas ett underkapitel vid sidan om den engelsk- och tyskspråkiga litteraturen. Det handlar mer om en presentation av viktiga författare som Kullman, Wernström, Beckman, Pohl, Edelfeldt och Wahl än en analys, vilket författaren själv förklarar som en konsekvens av bristen på källor. Han tvingades gå över tyska och engelska artiklar för att få reda på mer om den svenska litteraturen. Han var även tvungen att läsa flera romaner i tysk översättning (Delbrassine, 2006: 6I-68). Bristen på översättningar begränsar självklart det direkta inflytandet och situationen försvåras genom att det i Frankrike ofta går lång tid mellan originalutgåvan och översättningen.

\section{Nyutgåvor av klassikerna}

De mest kända svenska barnboksfigurerna i Frankrike är Nils Holgersson, Pippi Långstrump och Emil i Lönneberga. Alla tre böckerna har haft en intressant utveckling vad gäller översättningen. Den kompletta versionen av Nils Holgerssons underbara resa kom ut så sent som I990. I den första versionen från I9I2 är bara 24 av 55 kapitel översatta helt och utan ändringar. I den andra versionen från 1923 har översättaren varit tvungen att skriva om stora delar av boken för att få ner sidantalet till hälften gentemot originalet. Detta är dock inte angivet och läsaren riskerar därmed att utgå ifrån att det är en översättning trots att det inte kan kallas annat än en adaptation. Versionen för skolan som författaren själv kortade ner I92 I har dock aldrig översatts. De senaste årtiondena har franska barn lärt känna Nils framför allt genom den illusterade boken från I 989 som omarbetats av R. Alsberg 
och som översatts troget av A. Ségol. Där står det tydligt på försättsbladet att det är en adaptation. Boken har tryckts i flera upplagor och det är den som rekommenderas på utbildningsdepartementets lista. En ny barnversion kom 2000 hos Hachette Jeunesse där många kapitel saknas och där ändringar är gjorda i underkapitel, i rubriker och på meningsplanet. På baksidan kan man trots detta läsa: "Ni adaptation, ni résumé, ce livre propose une VERSION ABRÉGÉE du texte original” (Lagerlöf, 2000). Att franska barn känner till Nils idag beror framför allt på den japanska teckande teveserien som visats i Frankrike sedan I983, där man har lagt till en rollfigur, en hamster som heter Quenotte. Historierna är också anpassade till barn t.ex. genom att de får ett lyckligare slut. Smirre lämnar till slut Nils ifred för att han blir kär i en vacker rävhona istället för att hamna i exil (Jarl Ireman, 20I I).

Att Pippi blev censurerad vet vi om idag framför allt tack vare C. Heldners artiklar (Heldner, 1992 \& 2004) och också att en fullständig version kom ut I995. M. Loewegrens första översättning Mademoiselle Brindacier (I95I) som motsvarar de två första Pippi-böckerna är dock mer trogen originalet än vad som brukar konstateras. Loewegren gör till och med i sitt ordval huvudpersonen fräckare än vad hon är på svenska. Den börjar emellertid med följande kommentar från förlaget i syfte att undvika att franska barn tar efter Pippis beteende: "Fifi Brindacier est très populaire en Suède. Ce personnage de fillette dotée d'une force physique extraordinaire, n'est pas emprunté à la vie réelle. Il ne doit son existence qu'à l'imagination de l'auteur" (Lindgren, I95 I: 6). Det var först I 962 som en ny version kom ut med tre kapitel borttagna, där Pippi är som mest rebellisk. ${ }^{10}$ Avsnitt där hon berättar otroliga historier ("ljuger”) har också klippts bort. Den första av de här versionerna har fallit i skymundan och man brukar prata om den censurerade versionen från I95 I som alltså inte finns (Dupont, 2013: 32-40). Att böckerna i Bibliothèque rose adapterades var en vanlig företeelse för att de skulle närma sig den franska mentaliteten och förenkla förståelsen för barnet. Fifi blev populär tack vare sin uppnosighet och självständighet (trots att hon i den andra versionen fått en betydligt snällare framtoning) och boken blev en succé, trots censuren skulle man ha lust att säga även om det snarare var tack vara den. Frankrike var helt enkelt inte redo för Pippi Långstrump på den tiden. Några decennier senare var situationen en annan och det var hög tid för en nyöversättning. A. Gnaedigs översättning från 1995 är fullständig, men det finns fortfarande detaljer där den frångår Lindgrens text (Heldner, 2004: I 8-20). Följande exempel visar att Pippi på franska blir olydig med vilje vilket inte riktigt är 
författarens syfte. När hon ska på tekalas oroar hon sig över att inte kunna uppföra sig ordentligt och säger:

Je fais de mon mieux, crois-moi, mais j'ai remarqué à plusieurs reprises que les gens trouvaient que je manquais de tenue - et pourtant, je me suis toujours conduite du mieux possible. En mer, on faisait toujours très attention à ça. Mais je vous promets que je serai impeccable aujourd'hui et que vous n'aurez pas honte de moi. (Lindgren, 2007: 96)

I originalet förklarar Pippi att till sjöss var det inte viktigt vilket förklarar varför hon inte vet hur man ska uppföra sig (Lindgren, 2005: 99). På franska har hon lärt sig men kan ändå inte, vilket är värre och förändrar bilden av henne. Vanligt är också att översättare i allmänhet rättar utryck som svenska författare medvetet ändrat. När Astrid Lindgren låter Pippis pappa säga att det är lika omöjligt för honom att sjunka som för en kamel att trä på en synål, har man på franska valt det bibliska uttrycket ordagrannt: "Cela m'est tout aussi impossible qu'à un chameau de passer par le chas d'une aiguille" (Lindgren, 2007: 2I I). Det kan självklart vara en missuppfattning men troligare är att man vill ge barn det rätta uttrycket och att franska språket inte lika lätt tillåter sådana ordlekar. Även om boken fortfarande läses är Fifi Brindacier idag mest känd från den tecknade teveserien som visats regelbundet i Frankrike sedan I $998^{\text {II }}$. Emil $i$ Lönneberga översattes först under titeln Zozo la Tornade och han läspar vilket gett honom smeknamnet Zozo (Englund Dimitrova, 2002: 98). Den första boken kom ut 1973 och fortsättningarna på 80-talet. Samma översättning publicerades igen 2001/2003 och finns forfarande tillgänglig i handeln och på biblioteken. En ny översättning av Gnaedig kom 2008 där boktiteln och innehållet bättre motsvarar originalet. Att Emil på franska länge haft ett talfel beror på att han är smålänning.

Och så talade han småländska, det lilla livet, fast det kunde han inte hjälpa. Det gör man i Småland. När han ville ha sin mössa, då sa han inte som du: 'Jag vill ha min mössa.' Han sa så här: 'Jag vill ha mi mysse!' (Lindgren, 2002: 5-6)

I 1973 års översättning:

Ses parents l'avaient en réalité baptisé Émil. Mais comme il zozotait légèrement, on l'avait surnommé Zozo et cela lui était resté. [...] À vrai dire, il faisait un peu exprès de zozoter. En outre il s'entêtait à parler un langage enfantin. Or, tout petit, il avait cru comprendre 'cache-tête" pour "casquette'. [...] 'Ze veux ma cache-tête' (Lindgren, I973: 7-9) 
När han på svenska säger "söppe" blir det "potaze" på franska (Lindgren, I978: I9). De dialektala orden blir alltså barnspråk och talfel, vilket kan kännas väl drastiskt även om sådana ändringar alltså var accepterade på 70-talet. Gnaedig väljer 2008 följande lösning:

Il parlait parfois le patois du Småland. Il n’y était pour rien: dans cette région, on parlait un patois. C'est comme ça. Quand il voulait mettre sa casquette, il ne disait pas, comme toi: 'Je veux ma casquette!', il disait 'Je veux ma gampette' (Lindgren, 2008: I0).

Ordet "gampette" är benämningen på en sort keps av samma typ som den han har men det är inte ett dialektalt ord. När det gäller soppan används ordet "tambouille" (Lindgren, 2008: I9-20) som betyder maträtt och ofta används negativt, en osmaklig rätt. Det svåra dialektproblement är ännu inte löst.

Klassiker som dessa har alltså på senare år nyöversatts på ett mer troget sätt och publicerats med de svenska illustrationerna, men de tidigare versionerna har lästs och läses fortfarande av många. Figurerna är också kända genom de teckande teveserierna. Det är därför svårt att veta vilken bild franska läsare har av dem.

\section{Den realistiska samtidsromanen för ungdomar}

Svårigheten med svenska ungdomsromaner idag är att de ibland är alltför nydanande, både tematiskt och stilistiskt. Enligt Routisseaus definition är många av dem initationsromaner, där huvudpersonen söker sin identitet men där innehållet också ska förändra läsaren. Dessa berättelser handlar ofta om tabubelagda ämnen som sexualitet och död och överskrider gränser (Routisseau, 2008: 57-58). Genom att säga allt utsätter man ungdomarna för det man vill skydda dem från. Debatten idag handlar om hur långt man kan gå. Om kunskap kommer av att gränserna överskrids, vad kan man i så fall lära sig när dessa gränser väl är överskridna? Alla ämnen finns representerade i den franska ungdomslitteraturen trots den franska lagen och tendensen går mot ett överskridande av tabun. Men ett tydligt slut, vilket innebär att läsaren kan avsluta och gå vidare, ses generellt sett som en nödvändighet (Routisseau, 2008: 22). Läsarna anses klara svåra ämnen men det måste finnas ljus och sluta positivt, vilket svenska romaner inte alltid gör. Det är det som gör att en författare som Pohl är svår att publicera i Frankrike. Flera franska författare anser för övrigt det vara begränsande att tvingas undvika förtvivlan (Delbrassine, 2006: 276). Därutöver innehåller svenska romaner 
ibland ett mångtydigt slut vilket kräver mer av läsaren och hens förmåga att skapa sitt eget slut. Det kan förklara varför en bok som Svenne (2006) av P. Nilsson inte är översatt trots att ämnet (politisk populism och främlingsfientlighet) är aktuellt även i Frankrike.

Några teman verkar fortfarande vara svåra att behandla, vilket märks vid översättningen. Skämtsamma och elaka kommentarer om lärare tonas ofta ner. I A.-G. Winbergs Ce jeudi d'octobre, blir läraren i originalversionen totalt handfallen och bortgjord, men har mer värdighet på franska (Winberg, I976: 8). Ett senare exempel är J. Thydells Des étoiles au plafond där en tjej i det svenska originalet kallar sin lärare Britta för Bitte-Bittan inför henne, vilket på franska bara blir Britta, eftersom det är svårt att tänka sig att en fransk högstadieelev kallar sin lärare vid öknamn öppet på detta sätt (Thydell, 20I0: 49).

Sex är fortfarande ett komplicerat ämne i fransk ungdomslitteratur, vilket författare beklagar i intervjuer (Delbrassine, 2006: 274-275). I och med att sexualiteten är en stor del av ungdomars liv (i handling eller tanke) kan det kännas absurdt att inte skriva om det, särskilt med tanke på vad som finns att tillgå på Internet. Debatten fick ny fart nyligen då M. Blackmann efterlyste mer sex i ungdomslitteraturen. Reaktionerna i fransk press visar på ett visst stöd men också på en stor försiktighet. ${ }^{\mathrm{I2}}$ Det behövs en motvikt till pornografin, men det anses viktigt att författaren hittar rätt sätt att beskriva det på. I debatten refereras till engelskspråkiga författare, som är mer kända än de svenska och kan läsas i originalversionen. Svenska romaner beskriver ibland sexuella scener på ett detaljerat och konkret sätt, eller t.o.m. på ett sätt som uppfattas som våldsamt och känslolöst. Här spelar åldern på den tänkta läsargruppen in. Riktar sig förlagesserien till unga vuxna kan även sexuella scener översättas, men om den riktar sig till ı०-I 2-åringar är det mer problematiskt, vilket förklarar varför $\mathrm{M}$. Nilsson har självcensurerats av förlaget. I hennes bok Pourquoi mon père porte de grandes chaussures (20II) är några stycken som handlar om sexualitet borttagna eller omskrivna. I en scen får Gordon inte titta på Semlans snippa utan bara på hennes bröst och han får behålla kläderna på:

Ibland vill Gordon leka kärleksleken. Då pussas vi en stund, helst på en säng, med lite skön musik i bakgrunden. Och ibland vill han titta på min snippa. Då får han det och blir röd om kinderna som om han har feber. Jag blir också het om kinderna för jag gillar när han kollar, mer än att titta på hans snopp. Sen sitter vi en stund och blir allt hetare om kinderna tills vi drar på oss kläderna igen och fortsätter med läxan eller nåt. (Nilsson, 2009: I $4-\mathrm{I} 5$ ) 
Parfois Gordon veut jouer au jeu de l'amour. Alors nous nous embrassons pendant un moment, de préférence sur un lit, avec un peu de jolie musique en fond sonore. Et parfois il veut voir ma poitrine. Je le laisse faire et ses joues deviennent aussi rouges que s'il avait de la fièvre. Les miennes me chauffent aussi parce que j'aime bien quand il regarde, je préfère ça plutôt que de zieuter son zizi. Puis nous restons assis quelques instants et nos joues sont de plus en plus brûlantes, jusqu'à ce que je me rhabille et que nous continuons nos devoirs ou entreprenions autre chose. (Nilsson, 20I I: I7)

Förläggaren ansåg dessutom det vara olämpligt att låta en I2-årig flicka prata om sin pappas snopp så hela stycket som följer på svenska togs bort. En bok som K. Mazettis Entre Dieu et moi, c'est fini handlar däremot om en I6-åring och presenteras hos Gaïa/Babel som "littérature générale". Här översätts texten troget även när det pratas om sex (Mazetti, 20I I: 92) och omslaget betonar den sensuella aspekten. De olika förlagen har här inte samma inställning, men överlag kan man säga att t.ex. en bok som Regn och åska (20II) av H. Lindqvist som detaljerat beskriver sex mellan två unga män ännu riskerar att kortas ner i Frankrike, liksom Pohls svåra men viktiga bok Nu heter jag Nirak (2007), om de inte publiceras som just "littérature générale", d.v.s. skönlitteratur för vuxna.

Våld och död (inklusive självmord) är ämnen som idag är väl representerade i Frankrike. Men även här är det bristen på tydliga svar, liksom bristen på hopp, som gör den svenska litteraturen svårpublicerad. Det finns en del franska böcker som talar om döden på ett mörkt och hopplöst sätt men de har kritiserats för det (Delbrassine, 2006: 334). En bok som S. Castas Spelar död (r 999) är visserligen våldsam och ger ingen klar sanning och lösning, men trots allt slutar romanen med försoning och hopp. Boken kom ut 2004 på Thierry Magnier.

Detta förlag karakteriseras av ett enkelt format, korta böcker, ofta med berättande i första person, vilket väl stämmer överrens med många svenska böcker. Även här blir böckerna trots allt mer litterära på franska. Vid översättningen är i allmänhet en "förhöjning" av stilnivån nödvändig. Det handlar om en omstrukturering på syntaktisk nivå och om en "förfining" av stilen (Gossas \& Lindgren, 2010: 7; Lindgren, Andersson \& Renaud, 2007: 9I). Korta, konkreta meningar skrivs ihop till en lång med flera satser, samordning görs till underordning, och upprepningar tas bort. Den svenska stilen anses helt enkelt vara för enkel, även för unga läsare. Översättarens roll är därför också att arbeta om stilen, vilket påverkar berättarrösten. För att underlätta för unga franska läsare läggs istället ofta in pauser, i form av fler och kortare 
kapitel och stycken ${ }^{13}$. Ändringar kan också ske vad gäller typografin för t.ex. dialoger, i syfte att göra det lättare för läsaren att se vem som pratar. I Pohls Jan, mon ami blir således det indirekta talet en tydlig dialogsstruktur med direkt anföring (Pohl, I995: 30). En utveckling mot ett enklare och mer vardagligt språk sker dock inom BU-litteraturen i Frankrike.

\section{Avslutning}

Avslutningsvis kan man konstatera att det idag framför allt är svenska ungdomsromaner som kan vara problematiska då de ofta befinner sig på gränsen till vuxenlitteratur, s.k. cross-overlitteratur, medan man i Frankrike tydligare drar en gräns mellan BU-genren och allmän litteratur. Böcker av Pohl har publicerats alternativt för vuxna och för ungdomar i Sverige och Ett öga rött (2003) av J. H. Khemiri lanserades som vuxenbok men är lika mycket en ungdomsbok, vilket även kan gälla $\mathrm{H}$. Lindqvists böcker. Andra lanseras som ungdomsböcker men läses också av vuxna. De kan behandla svåra ämnen, innehålla öppna slut och brist på moralisk ståndpunkt, något som försvårar en utgivning i Frankrike. Ett motstånd finns fortfarande mot detaljerade sexuella scener. Mycket lite forskning har tillägnats den svenska BU-litteraturen på franska, vilket hör ihop med att många intressanta böcker ännu inte översatts. Influenserna från Sverige under de senaste decennierna verkar därför inte ha gått raka vägen mellan de två länderna, utan framför allt över Tyskland där fler översättning av svenska BU-böcker kommit ut.

Översättaren av svensk BU-litteratur har den svåra uppgiften att följa förlagens krav utan att ge avkall på trogenheten gentemot verket. Denna genre är svåröversatt eftersom den ofta har en stil som ligger långt från den franska, men samtidigt är den lättare att översätta i den mening att det här tillåts större frihet och anpassning till den nya målgruppen. Det kan kritiseras men det gör att böcker kan komma ut och förhoppningsvis sedan i nya upplagor som blir mer trogna originalet. Nils i denna artikels titel representerar klassikerna som regelbundet kommer i nya utgåvor och är kända hos en bred publik, men som också kommit ut i versioner som ligger långt från originalet. Semlan får stå som ett exempel på vad som kan ske idag när en bok anpassas till den franska unga läsaren och visar att översättningen fortfarande är problematisk. Förlagens försiktighet visar sig även i valet av böcker. Utvecklingen går dock framåt trots att lagen från I 949 fortfarande gäller och trots ett visst motstånd, vilket debatten om boken Tous à 
poil! (20I I) är ett talande exempel på. ${ }^{\mathrm{I} 4}$ Sederna förändras och gränsen för vad som är möjligt inom BU-genren vidgas. Hängivna översättare finns och förlagen visar större intresse. När det gäller ungdomsromaner spelar förlaget Thierry Magnier en viktig roll då de vågar ge ut böcker med teman som anses svåra. Det är också intressant att konstatera att flera av de böcker som kritiserats mycket i pressen också har valts ut för olika priser, vilket visar att en förändring sker. Framtiden ser således ljus ut för svensk BU-litteratur i Frankrike.

\section{Noter}

I. Lise av C. Lovera Vitali (Thierry Magnier, 2005) har t.ex. stycken utan punktuation.

2. Termen barn- och ungdomslitteratur förkortas till BU-litteratur i artikeln.

3. Med hänvisning till G. Klingbergs forskning på 70-talet.

4. Loi n ${ }^{\circ} 49-956$ du I 6 juillet 1949 sur les publications destinées à la jeunesse, article 2, version en vigueur au I9/5/20II.

5. En scen i boken Un pacte avec le diable (Syros, I988/2006) där huvudpersonen ligger en stund vid sidan av sin vän som dött av en överdos finns med i 2006 års upplaga, men inte i den första versionen.

6. Se t.ex. Douglas V. (2008 : II4-II 5).

7. Förlaget Thierry Magnier spelar sedan 1998 en viktig roll då deras serie "Grands romans" riktar sig till tonåringar och består till stor del av översättningar, flera från Sverige.

8. Listorna finns tillgängliga på http://eduscol.education.fr/cid $50485 /$ litterature. html (lägre stadier) och http://eduscol.education.fr/cid60809/presentation. html (högstadiet).

9. 20 I I publicerades totalt 69 nya svenska romaner (att jämföra med 52 året innan). Siffrorna fortsätter dock att öka enligt D. Ballus bibliografi Lettres nordiques: une bibliographie, del 2: 913 (ännu opublicerad), som anger 72 böcker 2012 och 802013.

Io. Det handlar om kapitlen där hon leker med poliserna, med tjuvarna och går på tekalas.

II. Före denna kanadensisk-tysk-svenska teveserie från 1997 visades i Frankrike från 70-talet den tysk-svenska från I969.

I 2. Se t. ex. Bourge J.-R. (20I3).

I3. Se t. ex. Mankell H. (20I2), Les ombres grandissent au crépuscule. Seuil. 
I4. J.-F. Copé kritiserade i februari 20 I 4 barnboken Tous à poil! (Franek C.\& Daniau, M. (200I), éditions du Rouergue) i TV för att illustrationerna visar nakna personer, men fick ett stort antal motreaktioner. Se t. ex. "Tous à poil!: des professionnels du livre posent nus en réponse à Copé », http:/www.lefigaro.fr/livres/2014/02/I9/03005-20I402 I9ARTFIGo0268

\section{Bibliografi}

Bourge, J. R. (2013), “Sexe: la littérature jeunesse pour concurrencer l'influence du porno sur les ados?”. Le Nouvel Observateur, 25 juni. http://leplus.nouvelobs.com/contribution/893070-sexe-la-litterature-jeunesse-pour-concurrencer-l-influence-du-porno-sur-les-ados.html (hämtad 20I4-05-I9)

Chelebourg, C. \& Marcoin, F. (2007), La littérature de jeunesse. Paris: Armand Colin.

Delbrassine, D. (2006), Le roman pour adolescents aujourd'bui: écriture, thématiques et réception. Paris: SCEREN - CRDP de l'académie de Créteil / La Joie par les livres.

Douglas, V. (2008), “Comment définir la littérature pour la jeunesse, ou le paradoxe insoluble”, in Cani I., Chabrol-Gagne N., d'Humières C. (red.), Devenir adulte et rester enfant? Relire les productions pour la jeunesse. Clermont-Ferrand: Presses Universitaires Blaise Pascal: I I 4-I I 5.

Dupont, C. (2013), La littérature de jeunesse suédoise en traduction française: une étude de Fifi Brindacier, de Jan, mon ami et de Pourquoi mon père porte de grandes chaussures. Mémoire de Master I sous la direction de A. Jarl Ireman, Université de Caen (opublicerad).

Englund Dimitrova, B. (2002), “Emil i Lönneberga - en läspande fransman?”, in Nystedt J. (red.), Språkbitar. Svenska Förlaget: 97-98.

Gossas, C. \& Lindgren, C. (2010), "Svensk barnboksexport till Frankrike trender och anpassning I989-2009", IASS, http://journals.lub.lu.se/ojs/ index.php/IASS2o Io/article/view/5033/4468 (hämtad 20I4-05-24)

Heldner, C. (I992), “une anarchiste en camisole de force”. La revue des livres pour enfants I45: 65-7I.

- (2004), "Hur Pippi Långstrump slapp ur sin franska tvångströja”. Barnboken. Stockholm: Svenska barnboksinstitutet: I I-22.

Jarl Ireman, A. (20гіa), “Au pays des merveilles boréales: La littérature de jeunesse scandinave”. Le Magazine Littéraire, mars 20I I: 82-84.

— (20Irb), "Le Merveilleux voyage du livre de Selma Lagerlöf”. Cahiers Robinson 29: 97-II2. 
Lindgren, C., Andersson, C. \& Renaud, C. (2007), "La traduction des livres pour enfants suédois en français”. La revue des livres pour enfants 234: 87-IOI.

Loi $\mathrm{n}^{\circ}$ 49-956 du I 6 juillet I949 sur les publications destinées à la jeunesse, article 2, http://www.legifrance.gouv.fr/affichTexte.do;jsessionid= A 6EEBF I 58 BF 5 I $60{ }_{5} \mathrm{Cog}_{6} 6{ }_{9} \mathrm{C}_{94} \mathrm{C}_{1} \mathrm{~F}_{7} \mathrm{C}_{1}$ I D.tpdjoo $2 \mathrm{~V}_{-} \mathrm{I}$ ? cidTexte= JORFTEXToooooo878I 75\&dateTexte=20 I007 Io (hämtad 20I4-04-I4)

- gällande version från I954/I2/OI till 20I0/07/I I http://www.legifrance. gouv.fr/affichTexteArticle.do;jsessionid=A6EEBF I 5 8BF 5 I $60{ }_{5} \mathrm{Cog}_{69} \mathrm{C} 94$ $\mathrm{C}_{\text {IF7 }} \mathrm{C}_{\text {I I D.tpdjoo2v_I }}$ ?idArticle=LEGIARTIooooo642 I 424\&cidTexte= JORFTEXToooo०o878 I 75 \&categorieLien=id\&dateTexte=20 I 007 I 0 (hämtad 20I4-04-I4)

- gällande version från 2010/07/I I till 2011/05/I9 http://www.legifrance. gouv.fr/affichTexteArticle.do;jsessionid=A6EEBF I 58 BF 5 I 605 Co9 69 94 $\mathrm{C}_{\text {IF }} \mathrm{C}_{\text {I I D.tpdjoo2v_I }}$ ?idArticle=LEGIARTIoooo22469876\&cidTexte= JORFTEXToooooo 878 I 75 \& categorieLien $=$ id \&dateTexte $=20$ I I 05 I 8 (hämtad 20I4-04-I4)

- gällande version från 20II/05/I9 http://www.legifrance.gouv.fr/affich TexteArticle.do;jsessionid=A6EEBF I 5 8BF 5 I $605 \mathrm{Cog}_{69} \mathrm{C}_{94} \mathrm{C}_{\text {I F }} \mathrm{C}_{\text {I I D. }}$ tpdjoo2v_I ?cidTexte=JORFTEXToooooo878 I 75 \&idArticle=LEGIARTI $000024039824 \&$ dateTexte=20I $40529 \&$ categorieLien=id\#LEGIARTI 000024039824 (hämtad 20I4-04-I4)

Monchaux, M.-C. (I988) [I985], Écrits pour nuire - Littérature enfantine et Subversion. Paris: UNI, 7 édition.

Nikolajeva, M. (I996), “Literature for Children and Young People”, in Warme L. G. (red.), A History of Swedish Literature. University of Nebraska Press: $495-5$ I 2 .

Pascua-Febles, I. (2010), "Translating for children: The translator's voice and power", in Di Giovanni E., Elefante C., Pederzoli R. (red.), Ecrire et traduire pour les enfants: Voix, image et mots. Bruxelles: Peter Lang: I6I-I 69 .

Ramdani, H. (2004), "Littérature jeunesse: l'offensive de la morale”. Bibliobs (Le Nouvel Observateur) 2004/I2/I4. http://bibliobs.nouvelobs.com/ jeunesse/2007 I 2 I 4.BIBo493/litterature-jeunesse-l-offensive-de-la-morale. html (hämtad 20I4-05-2I)

Routisseau, M.-H. (2008), Des romans pour la jeunesse? Décryptage. Paris: Belin.

Soulé, V. (I999), “Censures et autocensure”. BBF: 3. http://bbf.enssib.fr/ consulter/bbf-I999-03-0044-005 (hämtad 20I4-O5-2I) 
Terouanne, C. (2008), "Politiques éditoriales et traductions", in Diament N., Gibello C., Kiefé L. (red.), Traduire les livres pour la jeunesse: enjeux et spécificités. Hachette/ BNF/CNLJ- La Joie par les livres: 75-84.

\section{Skönlitteratur}

Beckman, G. (I976), Déchirer le silence (övers. Nyro C.). Paris: Éditions de l'Amitié.

Casta, S. (2006), Faire le mort (övers. Ségol A.). Paris: Thierry Magnier.

Lagerlöf, S. (I9I2), Le Merveilleux voyage de Nils Holgersson à travers la Suède, (övers Hammar, T.). Paris: Perrin.

- (I923), Le merveilleux voyage de Nils Holgersson à travers la Suède (övers. Hammar T.). Paris: Delagrave.

- (I989), Le merveilleux voyage de Nils Holgersson à travers la Suède (övers. Ségol A. \& Brick-Aïda P.). Paris: Père Castor Flammarion.

- ( I990), Le Merveilleux voyage de Nils Holgersson à travers la Suède (övers. (de) Gouvenain M. \& Grumbach L.). Paris: Actes Sud.

- (2000), Le Merveilleux voyage de Nils Holgersson à travers la Suède (övers. (de) Gouvenain M. \& Grumbach L.). Paris: Hachette jeunesse/Livre de poche.

Lindgren, A. (2002) [I963], Emil i Lönneberga. Stockholm: Rabén \& Sjögren.

- (2008), Les farces d'Emil (övers. Gnaedig A.). Paris: Hachette Jeunesse.

- (1962), Fifi Brindacier (övers. Loewegren, M.). Paris: Hachette.

- (2007) [I995], Fifi Brindacier (l'intégrale) (övers. Gnaedig A.). Paris: Hachette.

— (I95 I), Mademoiselle Brindacier (övers. Loewegren M.). Paris: Bibliothèque rose illustrée.

- (1973), Zozo la Tornade, (övers. Trébinjac S.). Paris: Bibliothèque rose.

Lindroth, M. (2007), Quand les trains passent (övers. Robnard, J.). Arles: Actes Sud junior.

Mankell, H. (20I 2), Les ombres grandissent au crépuscule (övers. Ségol-Samoy M. \& Serres, K.). Paris: Seuil.

Mazetti, K. (20I I) [2007], Entre Dieu et moi, c'est fini (övers. Stadler M. \& Clauss L.). Arles: Babel (poche).

Nilsson, M. (2007), Après le voyage scolaire (övers. Renaud J.). Paris: Bayard jeunesse. 
- (2009), Pappan med stora skorna. Stockholm: Natur \& Kultur.

- (20II), Pourquoi mon père porte de grandes chaussures et autres grands mystères de ma vie, (övers. Jarl Ireman A. \& Renaud J.). Montrouge: Bayard jeunesse.

Pohl, P. (I995), Jan, mon ami (övers. Ganedig A.). Paris: Gallimard.

Thydell, J. (2010), Des étoiles au plafond (övers. Ségol A.). Paris: Thierry Magnier.

Winberg, A.-G. (I976), Ce jeudi d'octobre (övers. Vincent E.). Paris: Éditions de l'Amitié. 